Bentham OPEN
CrossMark
Content list available at: www.benthamopen.com/TODENTJ/
DOI: $10.2174 / 1874210601610010486$

RESEARCH ARTICLE

\title{
Corrosion Analysis of an Experimental Noble Alloy on Commercially Pure Titanium Dental Implants
}

\author{
Manuel Alberto Bortagaray ${ }^{1}$, Claudio Arturo Antonio Ibañez ${ }^{2}$, Maria Constanza Ibañez ${ }^{3}$ and Juan \\ Carlos Ibañez ${ }^{4, *}$ \\ ${ }^{I}$ Prosthodontics, Private Practice, Santa Rosa, La Pampa, Argentina \\ ${ }^{2}$ Career Specialization in Oral Implantology, Faculty of Medicine, Catholic University of Córdoba, Argentina \\ ${ }^{3}$ Oral Implantology, Career Specialization in Oral Implantology, Faculty of Medicine, Catholic University of Córdoba, \\ Argentina \\ ${ }^{4}$ Dentistry, Career Specialization in Oral Implantology, Faculty of Medicine, Catholic University of Córdoba, \\ Argentina
}

Received: December 30, 2015

Revised: June 11, 2016

Accepted: August 7, 2016

\section{Abstract:}

Objective:

To determine whether the Noble Bond ${ }^{\circledR}$ Argen $^{\circledR}$ alloy was electrochemically suitable for the manufacturing of prosthetic superstructures over commercially pure titanium (c.p. Ti) implants. Also, the electrolytic corrosion effects over three types of materials used on prosthetic suprastructures that were coupled with titanium implants were analysed: Noble Bond ${ }^{\mathbb{B}}\left(\right.$ Argen $\left.^{\mathbb{B}}\right)$, Argelite $76 s f+{ }^{\circledR}\left(\right.$ Argen $\left.^{\circledR}\right)$, and commercially pure titanium.

\section{Materials and Methods:}

15 samples were studied, consisting in 1 abutment and one c.p. titanium implant each. They were divided into three groups, namely:

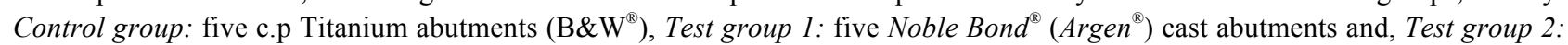
five Argelite 76s $f+{ }^{\circledR}\left(\right.$ Argen $\left.^{\circledR}\right)$ abutments. In order to observe the corrosion effects, the surface topography was imaged using a confocal microscope. Thus, three metric parameters (Sa: Arithmetical mean height of the surface. Sp: Maximum height of peaks. Sv: Maximum height of valleys.), were measured at three different areas: abutment neck, implant neck and implant body. The samples were immersed in artificial saliva for 3 months, after which the procedure was repeated. The metric parameters were compared by statistical analysis.

\section{Results:}

The analysis of the Sa at the level of the implant neck, abutment neck and implant body, showed no statistically significant differences on combining c.p. Ti implants with the three studied alloys. The Sp showed no statistically significant differences between the three alloys. The Sv showed no statistically significant differences between the three alloys.

\section{Conclusion:}

The effects of electrogalvanic corrosion on each of the materials used when they were in contact with c.p. Ti showed no statistically significant differences.

Keywords: Dental implants, Galvanic corrosion, Noble alloys, Noble bond ${ }^{\circledR}$, Suprastructure, Titanium.

\footnotetext{
* Address correspondence to this author at the Faculty of Medicine, Catholic University of Córdoba, Argentina., Obispo Oro 414, (5000) Córdoba,
} Argentina; Tel: +0054-0351-4680156; E-mail: dribanez@ibaimplantes.com 


\section{INTRODUCTION}

Due to their high cost, noble or semi-noble alloys with high content of gold and palladium, represent a problem when used to produce fixed prostheses over implants. Alternatively, newly developed alloys attempt to reduce corrosion without risk of losing the right physical properties. The different metallic materials used in such alloys have yielded varied results. Solá et al. [1] analysed resistance to corrosion of four noble alloys (Pontor $2^{\circledR}$, Cerapall $2^{\circledR}$, V-Gnathos Plus $^{\circledR}$ and Pagalin ${ }^{\circledR}$ ) and of a titanium alloy (Ti6Al4V) attached to commercially pure titanium (c.p. Ti). These authors observed a differential resistance to corrosion depending on the composition of each of the alloys used, despite the fact that all of them largely contain gold and palladium. For their part, as it has been shown, gold and palladium-based alloys present a lower dissolution rate and therefore greater corrosion resistance than those made up of non-noble base metals such as nickel- chrome or chrome-cobalt [2 - 6]. In order to improve corrosion resistance and "make them nobler" Sarantopoulos [7] studied two alloys (Noble Crown ${ }^{\circledR}$ and Noble Crown NF") made with the last two pairs of non-noble metals to which palladium was added, thus he concluded that the inclusion of this element has deleterious effects upon the physico-chemical properties of both alloys. Furthermore, Poljak-Guberina [8] pointed out the need to study processes which may enable to line or coat non-noble materials with higher corrosion-resistance ones, which will improve the behaviour of these alloys in the oral environment. Electro-chemical corrosion is the most important injury factor in dental work. It produces unintended wear of the metal surface, and a deterioration of the outer and inner layers caused by exposure to chemicals or electrochemical reaction of the surrounding area [9].

Given the nature of the medium in the oral cavity, it is especially important that the materials used show a high electrolytic corrosion resistance. The consequences of corrosion in alloys for dental use may result in negative biological, functional and aesthetic effects, of which the biological ones have higher significance. During corrosive processes, metal ions are freed into the medium and come into contact with neighbouring tissues and/or are spread throughout the entire body. Biological incompatibility of these ions can produce body injury, causing toxicity and risk of sensitization; therefore, it is fundamental the use of alloys made up of metals with a low degree of ionic [10].

Titanium properties make it ideal for use in dental implants, and it has been used successfully in dentistry for many years [4]. Its high resistance to corrosion results from the formation of a thin highly-adhesive layer of titanium oxide, being at the same time extremely biocompatible. However, one of the main problems of using titanium in the manufacturing of prosthetic structures results from the difficulty in handling it during the casting process.

According to the A.D.A. (American Dental Association) [11] classification system, noble alloys consist of at least $25 \%$ gold or metals of the platinum group.

Precious alloys (of high gold, silver, palladium and platinum content) are usually implemented as bases for fixed metal-ceramic prostheses. Compared to titanium or stainless steel alloys, precious alloys are distinguished by a high corrosion resistance (significantly increased when containing more than $75 \%$ gold [12]) as well as a low-to-moderate mechanical resistance.

Due to their low electrochemical stability, non-noble alloys or base metal alloys (Cr-Ni) combined with c.p. titanium, show a high corrosion level. Therefore, their implementation is contraindicated in the manufacturing of prosthetic suprastructures over implants. In an in vitro study of corrosion on alloys that are in contact with titanium [3], it was observed that those alloys based on non-noble metals $(\mathrm{Cr}-\mathrm{Co}, \mathrm{Cr}-\mathrm{Ni})$ present a higher dissolution rate than alloys based on noble metals ( $\mathrm{Au}, \mathrm{Pd})$.

Argen $^{\circledR}$ Corporation developed Noble Bond ${ }^{\circledR}$ alloy, which is made up of $75 \%$ base metals and $25 \%$ ruthenium, the latter also belonging to the group of noble metals (Noble Bond ${ }^{\mathbb{B}}$ Alloy -Composition: Ruthenium $25 \%$, Cobalt $40 \%$, Chrome 24\%, Gallium 11\%, Boron lines).

The purpose of producing this alloy is to improve the base metals alloys $(\mathrm{Cr}-\mathrm{Co})$ resistance to corrosion and, at the same time, to offer a low cost material with electrochemical characteristics similar to those of the noble alloys.

The success of noble alloys with high content of gold, palladium and c.p. titanium in the production of prosthetic structures over implant-supported suprastructure $[3,13,14]$ is well known because of both their biocompatibility and their resistance to corrosion. These are the reasons that led to a comparative analysis regarding the effects of electrolytic corrosion on two types of noble alloys: Argelite $76 s f^{\circledR}{ }^{\circledR}\left(\right.$ Argen $\left.^{\circledR}\right)$ and Noble Bond ${ }^{\circledR}\left(\right.$ Argen $\left.^{\circledR}\right)$ and c.p. titanium.

The main purpose of this study was to determine if the Noble Bond ${ }^{\mathbb{\otimes}}$ alloy is an electrochemically suitable material to make prosthetic suprastructures over c.p. titanium implants. 
Besides, the following aspects were analysed:

- Degree of electrolytic corrosion caused by the Noble Bond ${ }^{\mathbb{B}}$ alloy in combination with c.p. titanium;

- Degree of electrolytic corrosion caused by an alloy with high content of gold in combination with c.p. titanium;

- Degree of electrolytic corrosion caused by c.p. titanium over implants and abutment.

- A comparison of the results obtained for the three metals / alloys used in the implant-supported suprastructure.

\section{MATERIALS AND METHODOLOGY}

In this prospective experimental study $15 \mathrm{ad}$ modum transmucosal abutments (UCLA type) of $4.1 \mathrm{~mm}$ diameter coupled with 15 implants made of IV-degree titanium of $4 \mathrm{~mm}$ diameter and $10 \mathrm{~mm}$ length were used $\left(B \& W^{\circledR}\right.$ Buenos Aires, Argentina).

Five out of the 15 abutments were castings that used Noble Bond $d^{\circledR}$ alloy (Trial Group $1=$ TG 1); other five were castings that used Argelite $76 s f+{ }^{\circledR}$ noble alloy (Composition: Gold 1.8\%, Palladium 75.7\%, Ruthenium below 1\%, Indium 8\%, Gallium 6.3\%, Tin below 1\%, Copper 7.5\%, Borium below 1\%) (Trial Group $2=\mathrm{TG} 2$ ); and the remaining five were abutments made in c.p. titanium $\left(B \& W^{\circledR}\right.$ Buenos Aires, Argentina) (Control Group $\left.=\mathrm{CG}\right)$.

\section{Sample Preparation and Casting}

All the cast samples were prepared from castable plastic cylinder abutments and for the c.p. titanium samples machined straight abutments $\left(B \& W^{\circledR}\right.$ Buenos Aires, Argentina) were used.

The device used was a compact benchtop vacuum pressure casting machine with integrated power cooling and touch display Nautilus T from BEGO with Lolipot crucibles (Bremen, Germany). To avoid oxidation processes, casting was performed in new crucibles by induction in controlled atmosphere, following the specifications provided by each of the alloys' manufacturers. Once the UCLA abutments were cast, they were sand-blasted with non-recycled aluminium oxide- particle size 50 microns- at $60 \mathrm{psi}$, in order to remove oxide and lining remains.

Sample polishing was carried out with diamond rubber points and polishing paste following one direction and according to the manufacturer's specifications for both alloys. Finally, samples were decontaminated by immersion in distilled water and in ultrasonic cleaner for 10 minutes, procedure recommended by the manufacturers to remove polishing remains.

Fixation of prosthetic components on implants was carried out using c.p. titanium screws $\left(B \& W^{\circledR}\right.$ Buenos Aires, Argentina) torqued at $35 \mathrm{~N}$. Once the samples were obtained, they were placed in plastic containers and labeled (Fig. 1).

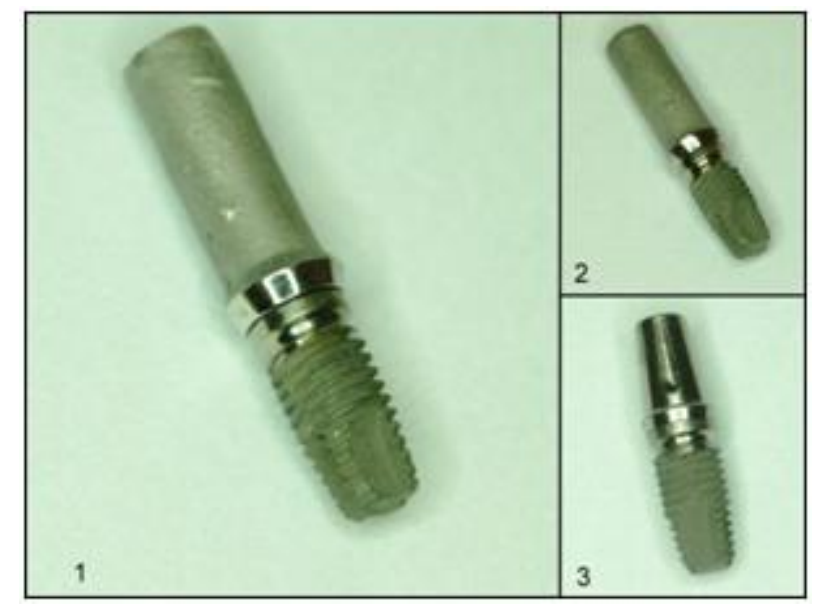

Fig. (1). Abutments cast on implants: 1. Noble Bond $d^{\circledR}$-Titanium, 2. Argelite ${ }^{\circledR}$ Titanium, 3. Titanium-Titanium.

\section{Sample Analysis and Treatment}

Each sample was analysed using a confocal microscope (OLYMPUS ${ }^{\circledR} L E X T$ OLS4000 3D Laser Measuring 
Microscope), designed to obtain nanometric images, 3D measurements and to measure roughness levels. The images obtained correspond to three different zones analysed (Fig. 2):

1. Abutment Neck (U Neck).

2. Implant Neck (I Neck).

3. Implant Body (I Body).

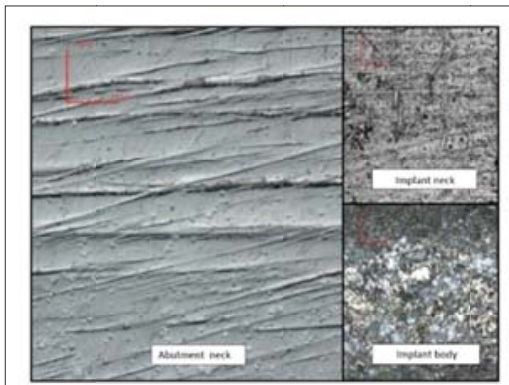

A-Noble Bond ${ }^{\mathbb{8}}$-titanium.

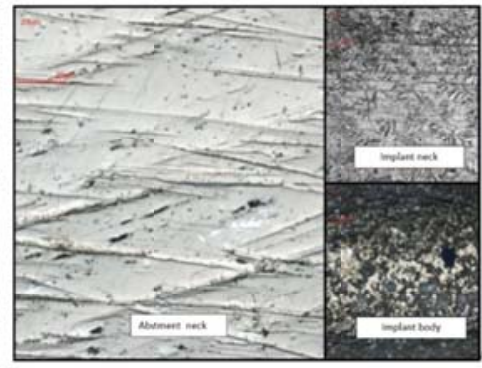

B-Argelite ${ }^{*}$-titanium

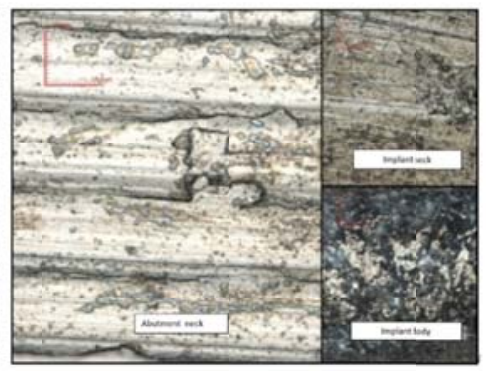

C- Titanium-titanium.

Fig. (2). The three different zones analysed in the samples.

The following 3D metric parameters were obtained in each of the photographed areas:

Sa: Arithmetical mean height of the surface.

Sp: Maximum height of peaks.

Sv: Maximum height of valleys.

After labeled, samples were placed in plastic containers and immersed in modified Ericsson solution as artificial saliva whose behaviour is quite similar to that of natural saliva and is generally used in electrolytic corrosion studies (composition: $\mathrm{NaCl}=0.600 / \mathrm{KCl}=0.720 / \mathrm{CaCl}_{2} .2 \mathrm{H}_{2} \mathrm{O}=0.220 / \mathrm{KH}_{2} \mathrm{PO}_{4}=0.680 / \mathrm{Na}_{2} \mathrm{HPO}_{4} \cdot 12 \mathrm{H}_{2} \mathrm{O}=0.856 / \mathrm{KSCN}=$ $0.060 / \mathrm{KHCO}_{3}=1.500 /$ Citric acid $\left.=0.030\right)[15]$.

Samples were kept immersed in the containers for three months, at the end of which, samples were analysed again using the same procedures applied at the beginning of the study (Fig. 3). The electrolyte was not changed during exposure.

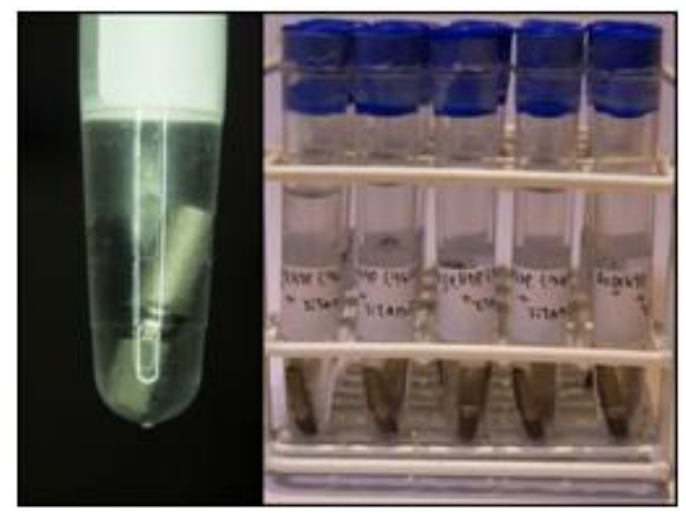

Fig. (3). Samples immersed in modified Ericsson solution and their storage.

An analytical technique by static immersion with an increased immersion time $[12,15]$ and in accordance with ISO/ TR 10271:1993 was the methodology used for sample treatment. 


\section{Statistical Analysis}

Parametric data obtained ( $S a, S p$ and $S v)$ in all samples, before and after immersing them in artificial saliva, were subjected to statistical treatment by running an ANOVA, LSD Fisher Alfa Test, and Tukey's Alfa Test.

\section{RESULTS}

The tables below show the metric parameters obtained through the images of the samples studied, before and after artificial saliva immersion (Tables 1-6).

Table 1. Data obtained from the Titanium-Titanium group before immersion in artificial saliva.

\begin{tabular}{|c|c|c|c|c|}
\hline Sample & Sector & $S a$ & $S p$ & $S v$ \\
\hline \multirow[t]{3}{*}{1} & Abutment Neck (U Neck) & 0.079 & 1.788 & 4.428 \\
\hline & Implant Neck (I Neck) & 0.098 & 1.299 & 1.546 \\
\hline & Implant Body (I Body) & 0.384 & 7.887 & 7.07 \\
\hline \multirow[t]{3}{*}{2} & Abutment Neck (U Neck) & 0.043 & 1.507 & 0.988 \\
\hline & Implant Neck (I Neck) & 0.059 & 0.903 & 0.872 \\
\hline & Implant Body (I Body) & 0.478 & 6.787 & 6.649 \\
\hline \multirow[t]{3}{*}{3} & Abutment Neck (U Neck) & 0.046 & 6.295 & 2.024 \\
\hline & Implant Neck (I Neck) & 0.09 & 3.028 & 2.045 \\
\hline & Implant Body (I Body) & 0.446 & 5.801 & 12.234 \\
\hline \multirow[t]{3}{*}{4} & Abutment Neck (U Neck) & 0.042 & 2.461 & 2.813 \\
\hline & Implant Neck (I Neck) & 0.196 & 2.775 & 4.318 \\
\hline & Implant Body (I Body) & 0.458 & 6.974 & 9.166 \\
\hline \multirow[t]{3}{*}{5} & Abutment Neck (U Neck) & 0.062 & 3.712 & 4.258 \\
\hline & Implant Neck (I Neck) & 0.06 & 1.862 & 1.18 \\
\hline & Implant Body (I Body) & 0.587 & 8.533 & 11.863 \\
\hline
\end{tabular}

Table 2. Data obtained from the Titanium-Argelite ${ }^{\circledR}$ group before immersion in artificial saliva.

\begin{tabular}{|c|c|c|c|c|}
\hline Sample & Sector & $S a$ & $S p$ & $S v$ \\
\hline \multirow[t]{3}{*}{6} & Abutment Neck (U Neck) & 0.039 & 1.955 & 0.809 \\
\hline & Implant Neck (I Neck) & 0.172 & 5.266 & 3.567 \\
\hline & Implant Body (I Body) & 0.345 & 8.564 & 14.786 \\
\hline \multirow[t]{3}{*}{7} & Abutment Neck (U Neck) & 0.042 & 4.226 & 1.565 \\
\hline & Implant Neck (I Neck) & 0.11 & 3.12 & 3.222 \\
\hline & Implant Body (I Body) & 0.361 & 14.215 & 12.9 \\
\hline \multirow[t]{3}{*}{8} & Abutment Neck (U Neck) & 0.038 & 3.178 & 1.883 \\
\hline & Implant Neck (I Neck) & 0.157 & 2.879 & 2.921 \\
\hline & Implant Body (I Body) & 0.542 & 12.845 & 13.927 \\
\hline \multirow[t]{3}{*}{9} & Abutment Neck (U Neck) & 0.229 & 4.729 & 3.563 \\
\hline & Implant Neck (I Neck) & 0.179 & 2.468 & 2.042 \\
\hline & Implant Body (I Body) & 0.394 & 19.706 & 15.759 \\
\hline \multirow[t]{3}{*}{10} & Abutment Neck (U Neck) & 0.392 & 8.676 & 6.768 \\
\hline & Implant Neck (I Neck) & 0.217 & 7.422 & 5.841 \\
\hline & Implant Body (I Body) & 0.538 & 9.46 & 12.604 \\
\hline
\end{tabular}

Table 3. Data obtained from the Titanium-Noble Bond ${ }^{\circledR}$ group before immersion in artificial saliva.

\begin{tabular}{|c|l|c|c|c|}
\hline Sample & \multicolumn{1}{|c|}{ Sector } & Sa & \multicolumn{1}{c|}{ Sp } \\
\hline 11 & Abutment Neck (U Neck) & 0.071 & 6.126 \\
\hline & Implant Neck (I Neck) & 0.114 & 16.417 \\
\hline & Implant Body (I Body) & 0.459 & 1.998 \\
\hline 12 & Abutment Neck (U Neck) & 0.068 & 8.046 & 3.795 \\
\hline & Implant Neck (I Neck) & 0.157 & 11.115 \\
\hline & Implant Body (I Body) & 0.54 & 2.231 \\
\hline
\end{tabular}




(Table 3) contd.....
\begin{tabular}{|c|c|c|c|c|}
\hline Sample & Sector & $\boldsymbol{S a}$ & $\boldsymbol{S} \boldsymbol{p}$ & $\boldsymbol{S} \boldsymbol{v}$ \\
\hline 13 & Abutment Neck (U Neck) & 0.057 & 1.283 & 3.266 \\
\hline & Implant Neck (I Neck) & 0.112 & 2.097 & 2.564 \\
\hline & Implant Body (I Body) & 0.512 & 7.298 & 7.57 \\
\hline 14 & Abutment Neck (U Neck) & 0.072 & 13.389 & 4.293 \\
\hline & Implant Neck (I Neck) & 0.117 & 3.959 & 5.794 \\
\hline & Implant Body (I Body) & 0.575 & 16.041 & 16.991 \\
\hline 15 & Abutment Neck (U Neck) & 0.046 & 2.328 & 2.235 \\
\hline & Implant Neck (I Neck) & 0.118 & 2.013 & 2.486 \\
\hline & Implant Body (I Body) & 0.556 & 7.962 & 9.815 \\
\hline
\end{tabular}

Table 4. Data obtained from the Titanium-Titanium group after immersion in artificial saliva.

\begin{tabular}{|c|c|c|c|c|}
\hline Sample & Sector & $S a$ & $S p$ & $S v$ \\
\hline \multirow[t]{3}{*}{1} & Abutment neck (U neck) & 0.075 & 1.48 & 1.178 \\
\hline & Implant neck (I neck) & 0.071 & 2.141 & 3.927 \\
\hline & Implant body (I body) & 0.342 & 4.836 & 10.087 \\
\hline \multirow[t]{3}{*}{2} & Abutment neck (I neck) & 0.048 & 2.04 & 1.23 \\
\hline & Implant neck (U neck) & 0.062 & 2.774 & 4.923 \\
\hline & Implant body (I body) & 0.504 & 14.755 & 14.682 \\
\hline \multirow[t]{3}{*}{3} & Abutment neck (U neck) & 0.046 & 1.097 & 6.274 \\
\hline & Implant neck (I neck) & 0.051 & 2.512 & 0.93 \\
\hline & Implant body (I body) & 0.486 & 10.274 & 10.177 \\
\hline \multirow[t]{3}{*}{4} & Abutment neck (U neck) & 0.046 & 1.527 & 0.858 \\
\hline & Implant neck (I neck) & 0.092 & 1.837 & 1.326 \\
\hline & Implant body (I body) & 0.476 & 10.758 & 13.079 \\
\hline \multirow[t]{3}{*}{5} & Abutment neck (U neck) & 0.058 & 1.251 & 1.282 \\
\hline & Implant neck (I neck) & 0.06 & 0.907 & 0.997 \\
\hline & Implant body (I body) & 0.565 & 6.804 & 12.324 \\
\hline
\end{tabular}

Table 5. Data obtained from the Titanium-Argelite ${ }^{\circledR}$ group after immersion in artificial saliva.

\begin{tabular}{|c|c|c|c|c|}
\hline Sample & Sector & $S a$ & $S p$ & $S v$ \\
\hline \multirow[t]{3}{*}{6} & Abutment neck (U neck) & 0.051 & 1.535 & 1.454 \\
\hline & Implant neck (I neck) & 0.171 & 3.706 & 3.366 \\
\hline & Implant body (I body) & 0.432 & 5.802 & 15.634 \\
\hline \multirow[t]{3}{*}{7} & Abutment neck (I neck) & 0.046 & 1.938 & 1.913 \\
\hline & Implant neck (U neck) & 0.119 & 4.068 & 4.883 \\
\hline & Implant body (I body) & 0.48 & 7.681 & 10.358 \\
\hline \multirow[t]{3}{*}{8} & Abutment neck (U neck) & 0.035 & 3.261 & 2.863 \\
\hline & Implant neck (I neck) & 0.15 & 2.949 & 2.387 \\
\hline & Implant body (I body) & 0.635 & 6.566 & 16.501 \\
\hline \multirow[t]{3}{*}{9} & Abutment neck (U neck) & 0.034 & 3.389 & 1.469 \\
\hline & Implant neck (I neck) & 0.186 & 3.955 & 4.319 \\
\hline & Implant body (I body) & 0.621 & 7.662 & 23.614 \\
\hline \multirow[t]{3}{*}{10} & Abutment neck (U neck) & 0.036 & 2.359 & 2.52 \\
\hline & Implant neck (I neck) & 0.158 & 4.507 & 3.914 \\
\hline & Implant body (I body) & 0.621 & 15.512 & 17.969 \\
\hline
\end{tabular}

Table 6. Data obtained from the Titanium- Noble Bond ${ }^{\boxplus}$ group after immersion in artificial saliva.

\begin{tabular}{|c|l|c|c|c|}
\hline Sample & \multicolumn{1}{|c|}{ Sector } & Sa & \multicolumn{1}{c|}{ Sp } \\
\hline 11 & Abutment neck (U neck) & 0.068 & 0.739 & 1.001 \\
\hline & Implant neck (I neck) & 0.116 & 4.692 & 2.518 \\
\hline & Implant body (I body) & 0.558 & 7.161 \\
\hline
\end{tabular}


(Table 6) contd.....

\begin{tabular}{|c|c|c|c|c|}
\hline Sample & Sector & $S a$ & $S p$ & $S v$ \\
\hline \multirow[t]{3}{*}{12} & Abutment neck (I neck) & 0.084 & 7.859 & 2.979 \\
\hline & Implant neck (U neck) & 0.152 & 3.847 & 4.119 \\
\hline & Implant body (I body) & 0.398 & 8.454 & 16.652 \\
\hline \multirow[t]{3}{*}{13} & Abutment neck (U neck) & 0.083 & 3.338 & 3.905 \\
\hline & Implant neck (I neck) & 0.126 & 3.379 & 4.021 \\
\hline & Implant body (I body) & 0.64 & 8.798 & 10.924 \\
\hline \multirow[t]{3}{*}{14} & Abutment neck (U neck) & 0.043 & 0.933 & 4.239 \\
\hline & Implant neck (I neck) & 0.096 & 2.216 & 2.862 \\
\hline & Implant body (I body) & 0.513 & 8.797 & 8.22 \\
\hline \multirow[t]{3}{*}{15} & Abutment neck (U neck) & 0.05 & 1.949 & 0.69 \\
\hline & Implant neck (I neck) & 0.129 & 2.905 & 2.261 \\
\hline & Implant body (I body) & 0.546 & 8.558 & 13.799 \\
\hline
\end{tabular}

\section{Sa; Arithmetical Mean Height of the Surface}

Although in the abutment neck (U Neck) Argelite ${ }^{\circledR}$ alloy showed a decrease of the Sa after saliva immersion, this variation was not significant. No statistically significant differences were found for the other two alloys Sa values at this level. The analysis of the Sa at the level of the implant neck (I Neck) showed no statistically significant differences on its surface in combination with the three studied alloys.

Similar results were found for the surface of the implant body (I Body) in contact with the three studied alloys, even though a slight increase of the Sa in the Argelite $^{\circledR}$ noble alloy was observed, differences were not statistically significant (Fig. 4).
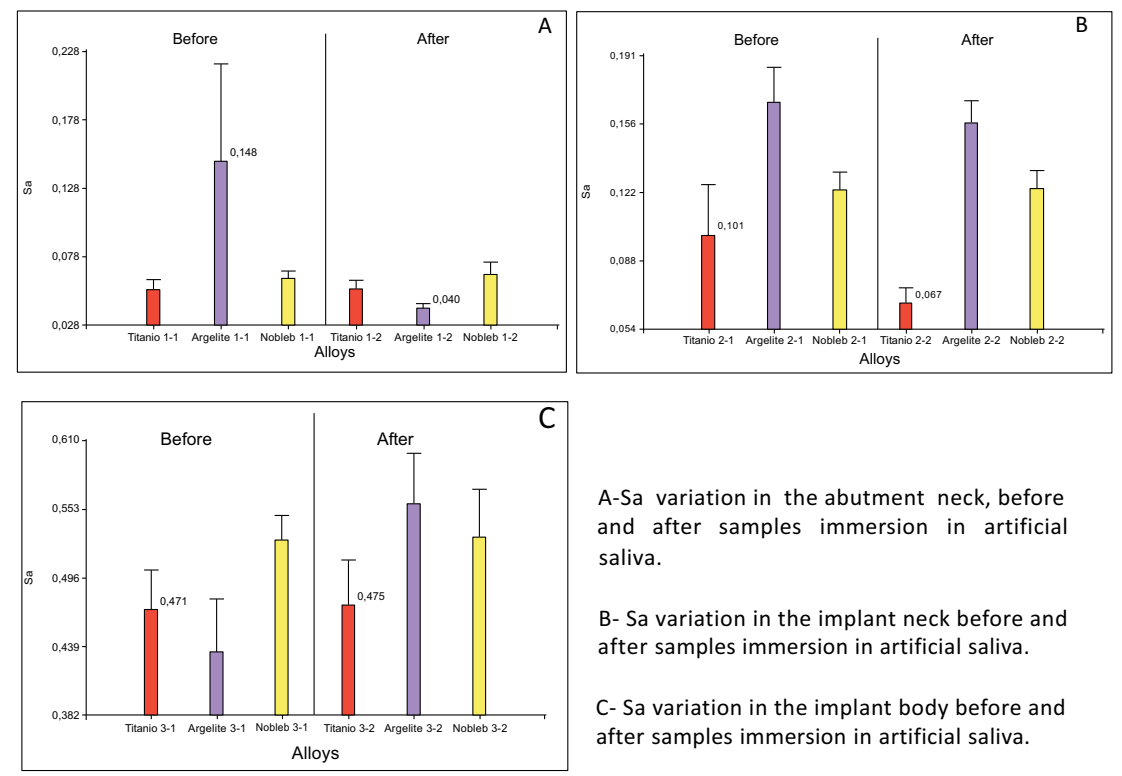

Fig. (4). Sa variation at the three levels measured, before and after samples immersion in artificial saliva.

\section{Sp, Maximun Height of Peaks}

As for Sp values in the implant neck (I Neck), although there was a decrease in values, the observed changes in the three samples, before and after immersion in artificial saliva, were not significant at the statistical level.

In the implant neck (I Neck) Sp values remained much the same.

As for Sp values in the implant body (I Body), an increase of this value was observed in the c.p. titanium alloy and a decrease of this same value in the Argelite ${ }^{\circledR}$ one; however, the differences found were not statistically relevant. In the case of Noble Bond $d^{\circledR}$, no statistically significant differences were found (Fig. 5). 

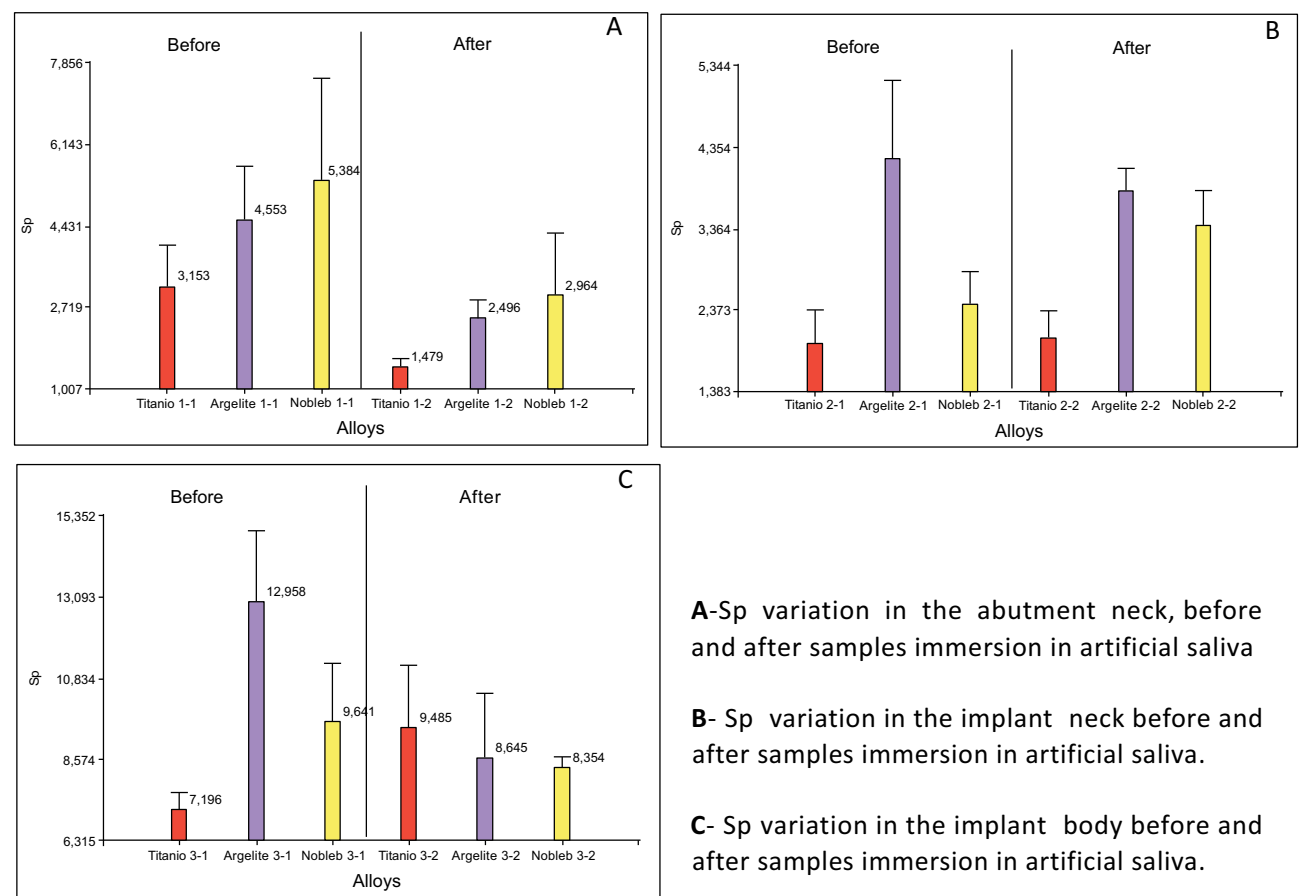

A-Sp variation in the abutment neck, before and after samples immersion in artificial saliva

B- Sp variation in the implant neck before and after samples immersion in artificial saliva.

C- Sp variation in the implant body before and after samples immersion in artificial saliva.

Fig. (5). Sp variation at the three levels measured, before and after samples immersion in artificial saliva.

\section{Sv, Maximun Height of Valleys}

In the abutment neck (U Neck), a slight decrease in the Sv values in the Noble Bond ${ }^{\mathbb{B}}$ alloy was observed, but it was not statistically significant. No significant differences were found in the Argelite ${ }^{\circledR}$ alloy or in c.p. titanium.

Comparing the results before and after artificial saliva immersion, no differences were observed at the level of the implant neck (I Neck) in any of the three alloys. Comparing results in the implant body (I Body) area, a slight increase in the Argelite $^{\circledR}$ alloy values was observed after immersion, but neither this increase nor the values obtained with the other two alloys were statistically significant (Fig. 6).
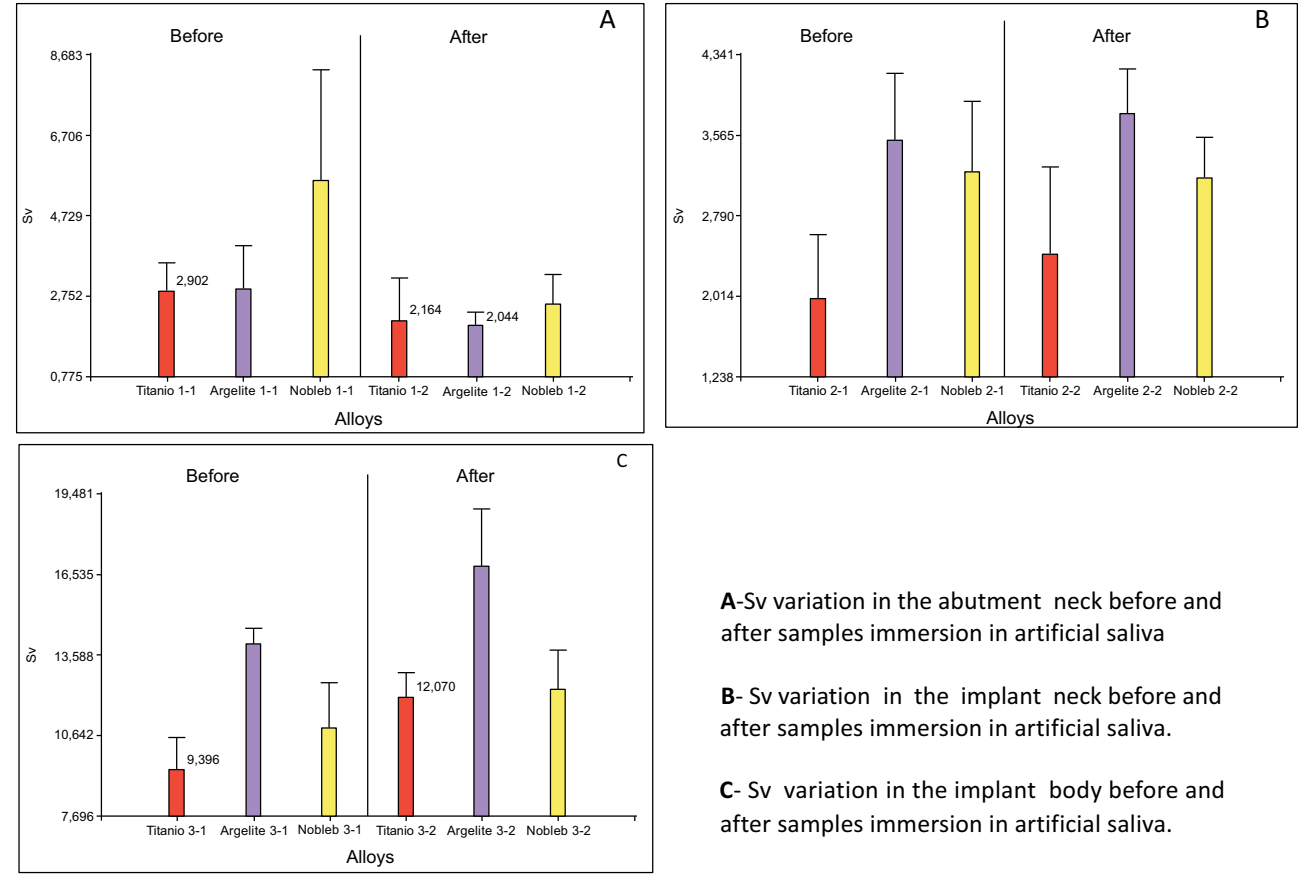

A-Sv variation in the abutment neck before and after samples immersion in artificial saliva

B- Sv variation in the implant neck before and after samples immersion in artificial saliva.

C- Sv variation in the implant body before and after samples immersion in artificial saliva.

Fig. (6). Sv variation at the three levels measured, before and after samples immersion in artificial saliva. 
An example of pre and post submersion of the samples is shown in Fig. (7)

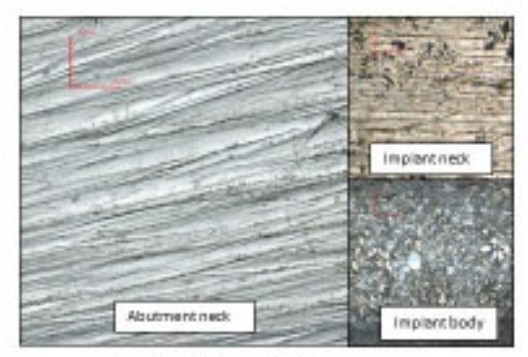

A- Noble Band E- titmium

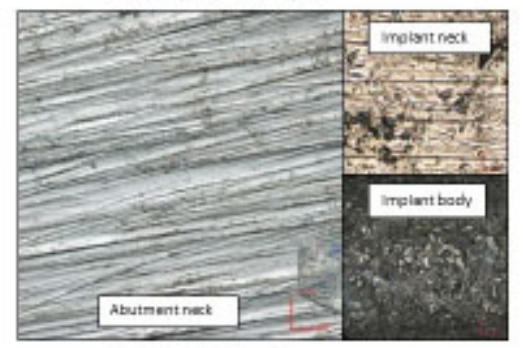

A-Noble Bond a thaium

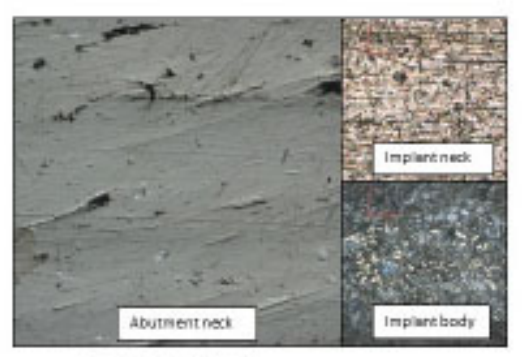

B-Agvite 2- titanium

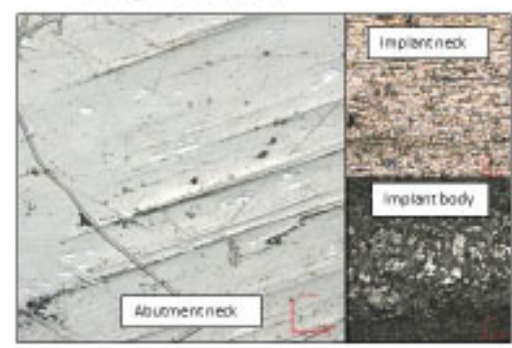

B. Argalite E- tharium

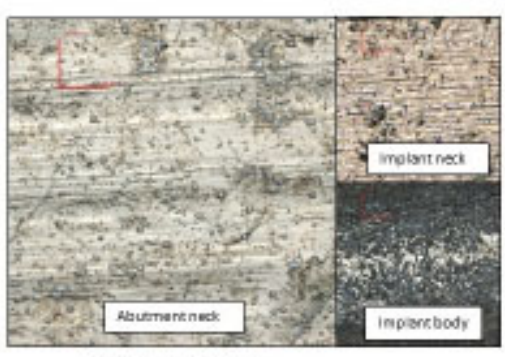

c- Titaniam- titanium

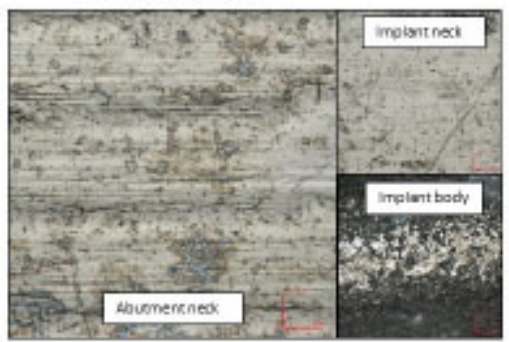

c. Itosilum tharium

Fig. (7). Pre and post sumersion image of one sample at the tree points observed.

\section{DISCUSSION}

All metals used in devices for biomedical prostheses degrade to a greater or lesser extent [4]. The purpose of this study was to determine if Noble Bond $d^{\circledR}$ alloy was a biomaterial electrochemically suitable to manufacture prosthetic suprastructures over c.p. titanium implants.

Adding a noble metal to non-noble alloys has already been done by Argen $^{\circledR}$ company in Noble Crown NF ${ }^{\circledR}$ (Co-PdCr-A) alloy and Noble Crown ${ }^{\circledR}$ (Ni-Pd-Cr) alloy. Although these alloys showed an increase in their nobility, they worsened the resistance to corrosion in comparison to the conventional $\mathrm{Co}-\mathrm{Cr}$ and $\mathrm{Ni}-\mathrm{Cr}$-base alloys from an in vitro study performed by Sarantopoulos et al. [7]. Unlike these results, in the present study and after immersion in artificial saliva for three months, there were no signs of corrosion at the alloy's surface level when ruthenium instead of palladium was used.

Regarding titanium abutments and titanium implants combined with the different alloys, no statically differences were observed between values obtained before and after immersing the samples in artificial saliva. This behaviour coincides with the one reported by other authors. Meffert et al. and Botha et al. concluded that initial rust gives titanium high resistance to corrosion, making it inert to tissues, and its low density provides it with a high resistance / weight relation making it highly biocompatible $[16,17]$.

Using titanium alloys to manufacture prosthetic suprastructures over implants avoids the problem of galvanic corrosion. A study carried out by Arismendi et al. [3] suggests that the best combination restoration-implant for trial conditions can be achieved by using c.p. titanium and a titanium alloy. Besides, titanium is considered one of the most corrosion-resistant materials used for biomedical purposes $[5,16,18]$. Two characteristics of titanium make it ideal for dental implants: its high mechanical resistance and its spontaneous passivation when in contact with water, air or tissue fluids [11].

The stable behaviour observed in noble alloys coincides with the results obtained in studies performed by other authors who concluded that noble alloys with high content of gold and palladium combined with c.p. titanium implants present high resistance to corrosion with minimum release of the metal's ions to the medium, as they develop a passivation mechanism when in contact with the medium [3, 5, 14]. Palladium-based alloys without silver show a rather passive behaviour and better than the Pd-Ag alloys [12]. Similarly, Cortada [9], in a galvanic corrosion study, concluded that palladium-based alloys present low levels of ions release in combination with titanium. In addition, it was shown that resistance to corrosion in silver-palladium based alloys is compatible with alloys with high contents of gold studied in artificial saliva $[3,5,14]$. In the present study there was no significant surface modification ( $\mathrm{Sa}, \mathrm{Sp}$, and 
Sv) of the samples at U neck, I neck or I body when Argelite $^{\circledR}$ alloy was used.

The methodology applied to treat the samples consists in an analytical technique through static immersion under ISO/TR 10271:1993 standards. The only variation introduced was an increase in the period of samples immersion [12, 19]. Further in vitro studies with longer periods of samples immersion in artificial saliva and in vivo studies are recommended.

\section{CONCLUSION}

No statistically significant differences between experimental Noble Bond $d^{\mathbb{R}}$ alloy, noble alloy and c.p. titanium alloys were found in the present study as regards electrogalvanic corrosion, measured through tridimensional changes that took place on the surface of the samples ( $\mathrm{Sa}, \mathrm{Sp}$, and $\mathrm{Sv}$ ) three months after having been immersed in artificial saliva, both at abutment level or at implant neck and body levels. Further research on longer periods of immersion is necessary to validate these preliminary results.

\section{CONFLICT OF INTEREST}

The authors confirm that this article content has no conflict of interest.

\section{ACKNOWLEDGEMENTS}

The authors thank Luis Croharé (ABO, Faculty of Dentistry, National University of Cordoba) for cooperation related to the statistical analysis of the data in this study.

\section{REFERENCES}

[1] Solá C, Amorim A, Espías A, et al. Galvanic corrosion behaviour of Ti and Ti6Al4V coupled to noble dental alloys. Int J Electrochem Sci 2013; 8: 406-20.

[2] Tuna SH, Pekmez NO, Keyf F, Canli F. The electrochemical properties of four dental casting suprastructure alloys coupled with titanium implants. J Appl Oral Sci 2009; 17(5): 467-75.

[http://dx.doi.org/10.1590/S1678-77572009000500022] [PMID: 19936528]

[3] Arismendi E, Agudelo A, Marín I, Peláez V, Echavarría V, Rojas M. Caracterización electroquímica de cuatro biomateriales metálicos de uso odontológico. Rev Fac Odont Univ Ant 2006; 17(2): 46-57.

[4] Sun D. On the corrosion behaviour and biocompatibility of palladium-based dental alloy. PhD Dissertation. Ohio, US: Graduate School of the Ohio State University 2004.

[5] Schmidli F, Jungo M, Jäger K, Lüthy H, Büchler M. Determination of the corrosion resistance of dental alloys with a new measurement method. Schweiz Monatsschr Zahnmed 2009; 119(6): 584-8.

[PMID: 20112638]

[6] Canay S, Öktemer M. In vitro corrosion behavior of 13 prosthodontic alloys. Quintessence Int 1992; 23(4): $279-87$. [PMID: 1502304]

[7] Sarantopoulos DM, Beck KA, Holsen R, Berzins DW. Corrosion of CoCr and NiCr dental alloys alloyed with palladium. J Prosthet Dent $2011 ; 105(1): 35-43$. [http://dx.doi.org/10.1016/S0022-3913(10)60188-6] [PMID: 21194586]

[8] Poljak-Guberina R, Knezovic-Zlataric D, Katunaric M. Dental alloys and corrosion resistance. Acta Stomat Croat 2002; 36(4): 447-50.

[9] Cortada M, Giner L, Costa S, Gil FJ, Rodríguez D, Planell JA. Galvanic corrosion behavior of titanium implants coupled to dental alloys. J Mater Sci Mater Med 2000; 11(5): 287-93.

[http://dx.doi.org/10.1023/A:1008905229522] [PMID: 15348025]

[10] Lucas LC, Lemons JE. Biodegradation of restorative metallic systems. Adv Dent Res 1992; 6: 32-7. [PMID: 1292459]

[11] Titanium applications in dentistry. J Amer Dent Assoc 2003; 134(3): 347-9. [http://dx.doi.org/10.14219/jada.archive.2003.0165] [PMID: 12699049]

[12] Sánchez Soler LA, Espías AF. Comportamiento químico de diferentes aleaciones utilizadas en prótesis fijas en relación a su liberación de iones. Dentum 2002; 2(1): 26-9.

[13] Taylor JC, Anderson GI, Sutow EJ, Driscoll CF, Mackey DC. The effects of the coupling of titanium implants and dissimilar metal abutments on osteoblast differentiation in vitro. Int J Oral Maxillofac Implants 1999; 14(6): 785-97. [PMID: 10612915]

[14] Gil FJ, Canedo R, Padrós A, Bañeres MV, Arano JM. Fretting corrosion behaviour of ball-and-socket joint on dental implants with different prosthodontic alloys. Biomed Mater Eng 2003; 13(1): 27-34.

[PMID: 12652020] 
[15] Quezada Castillo E, Duffo GS. Desarrollo de una saliva artificial para estudiar el comportamiento corrosivo de aleaciones dentales. Jornadas Sam/Conamet/SimposioMateria 2003; 6-35: 571-4.

[16] Meffert RM, Langer B, Fritz ME. Dental implants: a review. J Periodontol 1992; 63(11): 859-70. [http://dx.doi.org/10.1902/jop.1992.63.11.859] [PMID: 1453301]

[17] Botha SJ. Physical, mechanical, chemical, biological and optimal surface characteristics for bio-acceptability. J Dent Assoc S Afr 1997; 52(5): 273-82.

[PMID: 9461946]

[18] Raman V, Tamilselvi S, Nanjundan S, Rajendran N. Electrochemical behaviour of titanium and titanium alloy in artificial saliva. Trends Biomater Artif Organs 2005; 18: 137-40.

[19] Normas ISO. Dentistry determination of tarnish and corrosion of metals and alloys. ISO/TR 10271; 1993.

(C) Bortagaray et al.; Licensee Bentham Open

This is an open access article licensed under the terms of the Creative Commons Attribution-Non-Commercial 4.0 International Public License (CC BY-NC 4.0) (https://creativecommons.org/licenses/by-nc/4.0/legalcode), which permits unrestricted, non-commercial use, distribution and reproduction in any medium, provided the work is properly cited. 